\title{
CXCL14 wt Allele
}

National Cancer Institute

\section{Source}

National Cancer Institute. CXCL14 wt Allele. NCI Thesaurus. Code C49762.

Human CXCL14 wild-type allele is located within $5 q 31$ and is approximately $9 \mathrm{~kb}$ in length.

This allele, which encodes $C-X-C$ motif chemokine 14 protein, plays a role in both

monocyte chemotaxis and in monocyte-derived macrophage homeostasis. 